\title{
PROJECT BASED LEARNING UNTUK MENINGKATKAN BERPIKIR KREATIFSISWA SD PADA MATERI MAKANAN DAN KESEHATAN
}

\author{
Rena Surya Rohana ${ }^{1}$, Dinn Wahyudin² \\ ${ }^{1}$ Guru SDN Toyomerto I Kab. Serang \\ Email :renasuryailmi@gmail.com/dinn@upi.edu
}

\begin{abstract}
The fact the field of learning science in particular still tend to focus on textbooks and rarely use varied learning models so that creativity and mastery of concepts students become limited. The purpose of this research is the application of PBL models to improve the ability to think creatively and mastery of concepts students. The method used is a quasi-experimental method. The sample in this study were 70 students consisting of experimental class and control class. Hypothesis testing using t-test formula with menggunanakan software SPSS 17. Results of the study conducted shows the results of hypothesis testing using t-test. The first result with sig 0.009, then there is an increased ability to think creatively between the control class with a class experiment. Results of the second with sig $0.001<0.0251 / 2 \alpha$ which means Ho refused, then there is a difference between the increase in the ability to master the concept of control class with a class experiment.
\end{abstract}

Keywords: project based learning, creativity, concept

ABSTRAK

Kenyataan menunjukkan pembelajaran IPA masih berfokus pada buku teks dan jarang menggunakan model pembelajaran yang bervariatif sehingga kreativitas dan penguasaan konsep siswa menjadi terbatas. Tujuan penelitian penerapan model PBL untuk meningkatkan penguasaan konsep peserta didik. Metode yang digunakan dalam penelitian ini yaitu metode kuasi eksperimen. Penelitian ini dilakukan di SD Swasta Kartika Siliwangi XIX-3 Kabupaten Garut, sampel dalam penelitian ini adalah siswa kelas V yang berjumlah 66 siswa yang terdiri dari kelas eksperimen dan kelas kontrol berjumlah 33 siswa. Analisis penelitian menggunakan N-Gain dan pengujian hipotesis rumus $t$-test dengan menggunanakan software SPSS 17. Hasil penelitian menunjukkan bahwa pembelajaran berbasis proyek dapat meningkatkan kreativitas siswa lebih tinggi secara signifikan dibandingkan dengan kelas ekspositori dengan perbandingan di kelas eksperimen N-Gain 0,472 kategori sedang dan kelas kontrol N-Gain 0,223 kategori rendah.Hasil penelitian yang dilakukan menunjukkan hasil uji hipotesis dengan menggunakan t-test hasinya dengan nilai sig $0.009<1 / 2 \alpha$ yaitu 0,025 artinya $H_{0}$ ditolak maka terdapat perbedaan peningkatan kemampuan berpikir kreatif antara kelas kontrol dengan kelas eksperimen.

Kata kunci: pembelajaran berbasis proyek, berpikir kreatif

\section{PENDAHULUAN}

Pendidikan mempunyai peranan yang sangat menentukan bagi perkembangan dan perwujudan diri individu, terutama bagi pembangunan bangsa dan negara (Munandar, 2012:6). Kemajuan suatu bangsa bergantung kepada cara bangsa tersebut mengenali, menghargai, dan memanfaatkan Sumber Daya Manusia (SDM) nya, maka hal ini berkaitan erat dengan kualitas pendidikan yang diberikan kepada anggota masyarakatnya yaitu peserta didik. Menurut Undang-Undang Sistem Pendidikan Nasional No. 20 tahun 2003, pendidikan adalah suatu usaha sadar dan terencana untuk mewujudkan suasana dan proses pembelajaran agar peserta didik secara aktif mengembangkan potensi dirinya untuk memiliki kekuatan spiritual keagamaan, pengendalian diri, kepribadian, kecerdasan, akhlak mulia, serta keterampilan yang diperlukan dirinya, masyarakat, bangsa, dan negara.

Tujuan pendidikan pada umumnya ialah menyediakan lingkungan yang memungkinkan peserta didik untuk mengembangkan bakat dan kemampuannya secara optimal, sehingga ia dapat mewujudkan dirinya dan berfungsi sepenuhnya sesuai dengan kebutuhan pribadinya dan kebutuhan masyarakat. Pendidikan yang bertanggungjawab untuk memandu (mengidentifikasi dan membina) serta memupuk (mengembangkan dan meningkatkan) bakat peserta didik (Munandar, 2012:6).

Belajar tidak terlepas dari proses pembelajaran. Proses pembelajaran tidak 
terlepas dari faktor-faktor pendukungnya. Kebutuhan dan permasalahan dalam dunia pendidikan sangatlah kompleks mulai dari kebutuhan sumber belajar, guru yang handal, media pembelajaran, tempat atau fasilitas yang memadai, dan kebutuhan penunjang lainnya. Permasalahan dalam proses pembelajaran di sekolah lebih tepatnya di kelas dimana peserta didik ditempatkan sebagai pendengar saat guru menyampaikan konsep materi pembelajaran. Dengan demikian pesertra didik merasa bosan seolah tidak ada waktu untuk berpikir dan berkreasi secara efektif.

Salah satu landasan penyusunan yang diungkapkan pada standar isi pada Kurikulum Tingkat Satuan Pendidikan (KTSP) bahwa sains berhubungan dengan cara mencari tahu tentang alam secara sistematis, sehingga sains bukan hanya penguasaan kumpulan pengetahuan yang berupa fakta-fakta, konsepkonsep, atau prinsip-prinsip saja, tetapi juga merupakan suatu proses penemuan.

Sains memegang peran penting sebagai dasar pengetahuan untuk mengungkap fenomena alam. Oleh karena itu, sains menjadi sangat penting dalam kehidupan manusia sebagai bagian dari pengetahuan sekaligus memberi kontribusi besar bagi pengetahuan yang terkait dengan isu-isu global. Pengembangan kurikulum sains merenspon secara proaktif berbagai perkembanagn informasi, ilmu pengetahuan dan teknologi untuk meningkatkan relevansi program pembelajaran. Selain itu,sains memiliki peranan penting dalam meningkatkan mutu pendidikan khususnya menghasilkan peserta didik yang berkualitas yaitu mampu berpikir kritis, kreatif, logis, dan berinisiatif dalam menghadapi isu di masyarakat.

Penyelenggaraan pendidikan IPA (sains) di Sekolah Dasar merupakan salah satu mata pelajaran pokok yang rumusan tujuannnya merupakan perwujudan dan pengembangan pendidikan karakter bangsa. Tujuan pendidikan IPA di SD bukanlah sekedar agar siswa menguasai konten/materi IPA saja tetapi hendaknya menjadi wahana untuk mendidik siswa agar tumbuh dan berkembang menjadi manusia yang seutuhnya (Firman dan Widodo, 2008:31).

Faktor penyebab rendahnya kemampuan berpikir kreatif peserta didik tersebut karena pengaruh dari kurangnya pengetahuan, pengalaman, dan keengganan pendidik dalam menggunakan media dalam pembelajaran yang inovatif dan kreatif. Pada umumnya pembelajaran berlangsung secara konvensional, sehingga pembelajaran kurang menekankan untuk melakukan kegiatan eksplorasi, pencarian, dan penemuan secara mandiri. Pembelajaran demikian selain kurang meningkatkan penguasaan konsep sains dan kemampuan berpikir kreatif peserta didik, juga kurang memotivasi peserta didik untuk melakukan inkuiri dengan lebih baik. Alangkah lebih baik peserta didik yang menguasai konsep tidak hanya mampu menghafalkan sejumlah konsep yang telah dipelajarinya, tetapi ia mampu menerapkannya pada aspek lainnya dengan mengembangkan konsep berpikirnya

Bentuk pengajaran klasikal sampai sekarang masih merupakan bentuk pembelajaran yang paling banyak digunakan, namun bagibidang-bidang tertentu diperlukan bentuk-bentuk pembelajaran yang lain. Pembelajaran bermakna merupakan suatu hal yang harus diupayakan oleh setiap pengajar sains. Johnson (2007) mengemukakan bahwa ketika peserta didik mempelajari sesuatu dan dapat menemukan makna, maka makna tersebut dapat memotivasi mereka untuk belajar. Pembelajaran bermakna dapat melatih kebiasaan berpikir peserta didik dan memotivasi mereka untuk belajar. Salah satu strategi untuk membelajarkan peserta didik belajar bermakna adalah melalui pembelajaran berbasis proyek. Pembelajaran berbasis proyek merupakan salah satu model yang disarankan dalam kurikulum berbasis kompetensi di Sekolah Dasar (SD). Menurut Dikti (2008), pembelajaran berbasis proyek merupakan model belajar yang sistematis, 
yang melibatkan peserta didik dalam belajar pengetahuan dan keterampilan melalui proses pencarian atau penggalian yang panjang dan terstruktur terhadap pertanyaan yang otentik dan kompleks serta tugas dan produk yang dirancang dengan hati-hati.Pembelajaran berbasis proyek merupakan pembelajaran yang menggunakan masalah sebagai langkah awal dalam pembelajaran, mencari, dan mengumpulkan data dan informasi dari berbagai sumber untuk memecahkan masalah dan mengintegrasikan pengetahuan peserta didik, membuat keputusan dari berbagai macam alternatif solusi pemecahan masalah, dan beraktivitas secara nyata untuk menghasilkan produk dengan penuh kreativitas.

Pada umumnya Pembelajaran menggunakan metode ceramah dan lebih menekankan pada hafalan dan mencari satu jawaban yang benar terhadap soal-soal yang diberikan. Proses-proses pemikiran tingkat tinggi termasuk berpikir kreatif jarang dilatih kepada peserta didik. Salah satu kendala konseptual utama terhadap studi kreativitas adalah pengertian tentang kreativitas sebagai sifat yang diwariskan oleh orang yang berbakat luar biasa atau genius. Kreativitas diasumsikan sebagai sesuatu yang dimiliki atau tidak dimiliki dan banyak yang beranggapan bahwa tidak banyak yang dapat dilakukan melalui pendidikan untuk mempengaruhinya. Kendala dalam pengembangan kreativitas di antaranya yaitu (1) Anggapan bahwa kreativitas adalah pengertian tentang kreativitas sebagai sifat yang diwariskan oleh orang yang berbakat luar biasa atau genius, (2) Alat ukur (tes) yang biasa digunakan di sekolah yaitu tes inteligensi tradisional yang mengukur kemampuan peserta didik untuk belajar dan tes prestasi belajar (3) kurangnya perhatian dunia pendidikan dan psikologi terhadap kreativitas terletak pada kesulitan merumuskan konsep kreativitas itu sendiri, (4) tuntutan akan alatalat ukur yang mudah digunakan dan objektif telah mengalihkan perhatian dari upaya untuk mengukur kemampuan kreatif yang menuntut jenis tes divergen (5) keterbatasan penggunaan model stimulus respon, menjadi nyata jika kita berhubungan dengan prosesproses pemikiran yang tinggi, termasuk kreatif (Munandar, 2012:7).

Pembelajaran berbasis proyek merupakan pembelajaran yang berpusat pada proses, relatif berjangka waktu, berfokus pada masalah, unit pembelajaran bermakna dengan memadukan konsepkonsepdari sejumlah komponen baik itu pengetahuan, disiplin ilmu atau lapangan. Pada pembelajaran berbasis proyekkegiatan pembelajarannya berlangsung secara kolaboratif dalam kelompok yang heterogen. Selain itu pembelajaran berbasis proyek merupakan model pembelajaran yang memberikan kesempatan kepada guru untuk mengelola pembelajaran di kelas dengan melibatkan kerja proyek.

Perilaku kreatif adalah hasil dari pemikiran kreatif. Oleh karena itu, hendaknya sistem pendidikan dapat merangsang pemikiran, sikap, dan perilaku-perilaku kreatif dan produktif, di samping pemikiran logis dan penalaran. Kreativitas adalah kemampuan memulai ide, melihat hubungan yang baru, atau tak diduga sebelumnya, kemampuan memformulasikan konsep yang tak sekedar menghafal, menciptakan jawaban baru untuk soal-soal yang ada, dan mendapatkan pertanyaan baru yang perlu dijawab. Kreativitas adalah hasil dari interaksi antara individu dan lingkungannya.

Berpikir kreatif memiliki komponen meliputi fluency, flexibility, elaboration, dan originality. Kemampuan berpikir lancer (fluency) memiliki cirri-ciri seperti mencetuskan banyak gagasan, jawaban, penyelesaian masalah atau pertanyaan, memberikan banyak cara atau saran untuk melakukan berbagai hal. Kemampuan berpikir luwes (flexibility) memiliki ciri-ciri seperti melihat masalah dari sudut pandang yang berbeda, mencari banyak alternatif pemecahan masalah, mampu mengubah 
cara pendekatan aatau cara pemikiran. Keterampilan memerinci (elaboration) memiliki cirri-ciri mampu memperkaya dan mengembangkan suatu gagasan atau produk, memerinci secara detail dari suatu objek, gagasan atau situasi sehingga menjadi lebih menarik. Keterampilan berpikir orisinal (originality) memiliki cirri-ciri seperti mengungkapkan hal-hal yang baru dan unik yang tidak pernah terpikir oleh orang lain (Munandar, 1999:88).

Rumusan masalah yang dibahas dalam tulisan ini adalah (1) Apakah model pembelajaran Project Based Learning (PBL) dapat meningkatkan kemampuan berpikir kreatif peserta didik?; (2) Bagaimana tanggapan peserta didik terhadap penerapan model pembelajaran PBL pada materi makanan dan kesehatan?

Tujuan yang diharapkan dalam tulisan ini adalah untuk mengetahui model pembelajaran Project Based Learning (PBL) dapat meningkatkan kemampuan berpikir kreatif dan penguasaan konsep peserta ddidik serta ingin mengetahui bagaimanana tanggapan peserta diidik terhadap penerapan model pembelajaran PBL saat pembelajaran.

\section{METODE PENELITIAN}

Penelitian ini menggunakan pendekatan kuantitatif dengan metode penelitian kuasi eksperimen. Metode kuasi eksperimen digunakan dalam penelitian ini karena digunakan pengaruh perlakuan tertentu terhadap yang lain dalam kondisi yang terkendalikan (Sugiyono, 2012). Penelitian dilakukan terhadap kelas eksperimen yang menggunakan model pembelajaran Project Based Learning (PBL); sedangkan pembandingannya kelas kontrol menggunakan pembelajaran konvensional. Selain itu, penelitian kuasi eksperimen banyak digunakan dalam pendidikan atau bidang lain yang subjek penelitiannya manusia yang tidak dapat dimanipulasi dan dikontrol secara intensif.

Metode eksperimen semu ini digunakan untuk mengetahui kemampuan berpikir kreatif siswa antara siswa yang mendapatkan pembelajaran dengan model pembelajaran PBL dan yang mendapatkan pembelajaran dengan praktikum. Pada desain ini, peneliti menggunakan dua kelas yaitu kelas eksperimen dan kelas kontrol. Langkah selanjutnya adalah dilakukan uji pretestpada kedua kelompok tersebut meski diberikan perlakuan yang berbeda antara kedua kelompok tetapi untuk pengujian baik kelompok eksperimen maupun kelompok kontrol menggunakan perangkat tes yang sama.

Desain penelitian yang digunakan dalam penelitian ini adalah bentuk desain kuasi eksperimen Nonequivalent (PreTest and Post-Test) Control-Group Design. Pertimbangan menggunakan desain ini karena dalam penelitian ini kelompok eksperimen maupun kelompok kontrol tidak dipilih secara random.

Untuk memperoleh data pada kedua kelas tersebut diberikan tes awal (pretest) dan tes akhir (posttest), diberikan tes awal untuk mengetahui kemampuan awal peserta didik serta pengaruh variabel bebas dan variabel terikat. Hanya kelas eksperimen yang diberikan perlakuan. Desain ini mempunyai kelompok kontrol, tetapi tidak dapat berfungsi sepenuhnya untuk mengontrol variabel-variabel luar yang mempengaruhi pelaksanaan eksperimen (Sugiyono, 2012). Desain penelitian yang digunakan dalam penelitian ini dapat dilihat pada tabel 1 .

Instrumen tes yang digunakan pada penelitian ini yaitu soal uraian sebanyak 10 soal, angket dan observasi. Pengolahan data berupa penghitungan tes awal, tes akhir, N-Gain, serta pengujian hipotesis. Penghitungan Gain dan kriteria peningkatan Gain yang menggunakan rumus dari

Hake (Meltzer, 2002). Uji normalitas dan uji homogenitas dilakukan dengan menggunakan program SPSS versi 17, pada taraf signifikansi $\alpha=0,025$ serta pengujian hipotesis menggunakan t-test, angket dan 
Tabel 1

Desain Penelitian

\begin{tabular}{cccc}
\hline Kelompok & Pretest & Perlakuan & Posttest \\
\hline Eksperimen & $\mathrm{O}_{1}$ & $\mathrm{X}_{1}$ & $\mathrm{O}_{2}$ \\
\hline Kontrol & $\mathrm{O}_{3}$ & $\mathrm{X}_{2}$ & $\mathrm{O}_{4}$ \\
\hline
\end{tabular}

(Sumber: Sugiono, 2015)

Keterangan :

$\mathrm{X}_{1}$ : Pembelajaran dengan menggunakan pembelajaran PBL.

$\mathrm{X}_{2}$ : Pembelajaran dengan konvensional

$\mathrm{O}_{1} \quad$ : Pretest kelas eksperimen.

$\mathrm{O}_{2}$ :Postest kelas eksperimen.

$\mathrm{O}_{3} \quad$ :Pretest kelas kontrol.

$\mathrm{O}_{4}^{3} \quad$ :Postest kelas kontrol.

lembar observasi diuji secara kualitatif yaitu secara deskriptif dan dikonversi menjadi skala kuantitatif.

\section{HASIL DAN PEMBAHASAN}

\section{A. Peningkatan Kemampuan Berpikir Kreatif Siswa Sekolah Dasar}

Skor kemampuan berpikir kreatif yang diperoleh pada kelas eksperimen pada saat pretes skor maksimum yaitu 72 sedangkan skor minimum yaitu 39, sedangkan pada saat postes skor maksimum yaitu 94 dan skor minimum 56. Skor kemampuan berpikir kreatif yang diperoleh pada kelas kontrol pada saat pretest skor maksimum yaitu 67 sedangkan skor minimum yaitu 28. Pada saat postes skor maksimum yaitu 90 dan skor minimum 56.

Hasil tersebut dapat dilihat pada tabel 2.

Tabel 2

Kemampuan Berpikir Kreatif Kelas Eksperimen

\begin{tabular}{lcccccc}
\hline \multirow{2}{*}{ Berpikir Kreatif } & \multicolumn{3}{c}{ Kelas Eksperimen } & \multicolumn{3}{c}{ Kelas Kontrol } \\
\cline { 2 - 7 } & Pretes & Postes & N-gain & Pretes & Postes & N-gain \\
\hline Skor maksimum & 72 & 94 & 0,89 & 67 & 89 & 0,88 \\
\hline Skor minimum & 39 & 56 & 0,28 & 28 & 56 & 0,11 \\
\hline Skor rata-rata & 52,22 & 82,63 & 0,62 & 52,37 & 74,44 & 0,46 \\
\hline \% Skor rata-rata & 52,22 & 82,63 & 62,33 & 52,37 & 74,44 & 49,54 \\
\hline Simpangan baku & 8,51 & 8,39 & 0,21 & 8,76 & 10,63 & 0,22 \\
\hline
\end{tabular}

Berdasarkan data tabel 2 kemampuan berpikir kreatif kelas eksperimen memiliki rata-rata lebih tinggi dibandingkan dengan nilai rata-rata kelas kontrol.Rata-rata $\mathrm{N}$-gain kemampuan berpikir kreatif untuk kelas eksperimen termasuk kategori sedang $(0,62)$ dan rata-rata $\mathrm{N}$-gain kemampuan berpikir kreatif untuk kelas kontrol termasuk kategori sedang $(0,46)$.

Hasil uji normalitas dan homogenitas pretes, postes, dan N-gain kemampuan berpikir kreatif disajikan pada tabel 3 .

Tabel 3

Skor Pretes, Postes, dan N-gain Kemampuan Memecahkan Masalah

\begin{tabular}{|c|c|c|c|c|c|c|}
\hline \multirow[t]{2}{*}{ Komponen Uji } & \multicolumn{2}{|l|}{ Pretes } & \multicolumn{2}{|l|}{ Postes } & \multicolumn{2}{|l|}{ N-gain } \\
\hline & Eksp. & Kontr. & Eksp. & Kontr. & Eksp. & Kontr. \\
\hline Normalitas & 0,080 & 0,004 & 0,002 & 0,020 & 0,62 & 0,200 \\
\hline Homogenitas & \multicolumn{2}{|c|}{ - } & \multicolumn{2}{|c|}{ - } & \multicolumn{2}{|c|}{0,491} \\
\hline
\end{tabular}

Berdasarkan tabel 3 dapat dilihat nilai signifikansi kelas eksperimen dan kelas kontrol masing-masing 0,002 dan 0,020. Nilai signifikansi kedua kelas tersebut $<\alpha$
$(0,05)$. Hasil ini menunjukkan bahwa data postes kemampuan berpikir kreatif yang diperoleh dari kelas eksperimen dan kelas kontrol tidak berdistribusi normal. 
Berdasarkan tabel 3, didapat juga nilai signifikansi (Sig.) untuk data N-gain kelas eksperimen 0,062 dan nilai signifikansi kelas kontrol 0,200. Nilai signifikansi kedua kelas tersebut $>\alpha(0,05)$. Hasil ini menunjukkan bahwa data $\mathrm{N}$-gain kemampuan berpikir kreatif yang diperoleh dari kelas eksperimen dan kelas kontrol berdistribusi normal. Setelah diketahui bahwa N-gain kelas eksperimen dan kelas kontrol berdistribusi normal, maka langkah selanjutnya adalah melakukan uji homogenitas varians dan $\mathrm{N}$-gain. Berdasarkan Tabel 3 juga, diperoleh angka signifikansi $=0,491$. Oleh karena angka signifikansi $>\alpha(0,05)$, maka data $\mathrm{N}$-gain kelas eksperimen maupun kelas kontrol bersifat homogen atau memiliki varians yang sama.

\section{Uji Statistik Kemampuan Awal Berpikir Kreatif}

Untuk menguji apakah kemampuan awal berpikir kreatif pada kelas eksperimen dan kelas kontrol berbeda secara signifikan, maka digunakan uji statistik non parametrik dengan uji Mann Whitney U pada software SPSS 17. Uji ini dilakukan karena salah satu sampel berasal dari populasi yang tidak berdistribusi normal. Rumusan hipotesis kemampuan awal berpikir kreatif peserta didik pada kelas eksperimen dan kelas kontrol sebagai berikut: $\mathrm{H}_{0} \quad$ :tidak terdapat perbedaan kemampuan awal berpikir kreatif pada kelas eksperimen dan kelas kontrol.

$\mathrm{H}_{1} \quad$ terdapat perbedaan kemampuan awal berpikir kreatif pada kelas eksperimen dan kelas kontrol.

Hasil uji statistik kemampuan awal berpikir kreatif peserta didik kelas eksperimen dan kontrol dapat dilihat pada tabel 4.

Tabel 4

Hasil Uji Statistik Kemampuan Awal Berpikir Kreatif

\begin{tabular}{ccc}
\hline Nilai Asymp. Sig. (2-tailed) & Nilai $1 / 2 \alpha$ & Keterangan \\
\hline 0,770 & 0,025 & Ho diterima \\
\hline
\end{tabular}

Berdasarkan tabel 4 didapatkan nilai Asymp. Sig. (2-tailed) $=0,770$. Nilai tersebut $>1 / 2 \alpha(0,025)$, sehingga berdasarkan pengujian hipotesis, maka Ho diterima. Hasil ini menunjukkan bahwa antara kelas eksperimen dan kelas kontrol memiliki kemampuan awal berpikir kreatif yang tidak berbeda satu sama lain.

\section{Uji Hipotesis Perbedaan Peningkatan Kemampuan Berpikir Kreatif}

Untuk mengetahui perbedaan peningkatan kemampuan berpikir kreatif kelas eksperimen dan kelas kontrol dilakukan pengolahan terhadap nilai $\mathrm{N}$-gain kedua kelas tersebut. Uji hipotesis dilakukan dengan statistik parametrik independent sample t-test dengan menggunakan software SPSS 17. Hal ini karena data memenuhi uji prasyarat yang menunjukkan data $\mathrm{N}$-gain kemampuan berpikir kreatif kelas eksperimen dan kelas kontrol yang berdistribusi normal dan homogen. Rumusan hipotesis perbedaan peningkatan kemampuan berpikir kreatif pada kelas eksperimen dan kelas kontrol sebagai berikut:

$\mathrm{H}_{0}$ :tidak terdapat perbedaan peningkatan

kemampuan berpikir kreatif pada kelas eksperimen dan kelas kontrol.

$\mathrm{H}_{1}$ : terdapat perbedaan peningkatan

kemampuan berpikir kreatif pada kelas eksperimen dan kelas kontrol.

Hasil uji hipotesis perbedaan peningkatan kemampuan berpikir kreatif kelas eksperimen dan kelas kontrol dapat dilihat pada tabel 5.

Berdasarkan tabel 5 pada kolom Sig. (2-tailed) $0,009<1 / 2 \alpha(0,025)$, sehingga Ho ditolak. Hasil ini menunjukkan bahwa terdapat perbedaan peningkatan kemampuan berpikir kreatif antara kelas eksperimen dan kelas kontrol.

Berdasarkan data pengujian hipotesis di atas dalam penelitian ini hasil penelitian yang 
Tabel 5

Hasil Uji Hipotesis Perbedaan Peningkatan Kemampuan Berpikir Kreatif

\begin{tabular}{ccc}
\hline Nilai Sig. (2-tailed) & Nilai $1 / 2 \alpha$ & Keterangan \\
\hline 0,009 & 0,025 & Ho ditolak \\
\hline
\end{tabular}

dilakukan menunjukkan hasil uji hipotesis dengan menggunakan ${ }_{1}^{+}{ }^{+}$est. Hasilnya dengan nilai sig $0,009</ 2 \alpha$ yaitu 0,025 artinya $H_{\text {o ditolak maka terdapat peningkatan }}$ kemampuan berpikir kreatif antara kelas kontrol dengan kelas eksperimen.

Dari data di atas kemampuan berpikir kreatif peserta didik lebih baik pada kelas eksperimen yang mendapatkan pembelajaran berbasis proyek dibandingkan dengan peserta didik kelas kontrol yang mendapatkan pembelajaran konvensional. Begitu juga dengan kemampuan penguasaan konsep peserta didik lebih baik pada kelas eksperimen yang mendapatkan pembelajaran berbasis proyek dibandingkan dengan peserta didik kelas kontrol yang mendapatkan pembelajaran konvensional.

\section{B. Hasil Tanggapan Peserta Didik tentang Pembelajaran Berbasis Proyek}

Pada bagian ini disajikan tanggapan 33 orang peserta didik terhadap pembelajaran berbasis proyek pada materi makanan dan kesehatan yang dikumpulkan melalui pemberian kuesioner setelah selesai pembelajaran pada kelas eksperimen. Rangkuman tanggapan peserta didik dapat dilihat pada tabel 6 .

Tabel 6

Rangkuman Tanggapan Peserta Didik

\begin{tabular}{|c|c|}
\hline Aspek & Hasil \\
\hline $\begin{array}{l}\text { Respon terhadap } \\
\text { pembelajaran berbasis } \\
\text { proyek }\end{array}$ & $\begin{array}{l}\text { Sebagian besar ( } 51 \% \text { - } 75 \%) \text { peserta didik menyatakan bahwa: } \\
\text { - Mengikuti pembelajaran berbasis proyek merupakan pengalaman baru. } \\
\text { - Tertarik dengan pembelajaran berbasis proyek. }\end{array}$ \\
\hline $\begin{array}{l}\text { Respon terhadap konten } \\
\text { pembelajaran berbasis } \\
\text { proyek }\end{array}$ & $\begin{array}{l}\text { Sebagian besar }(51 \% \text { - } 75 \%) \text { peserta didik menyatakan bahwa: } \\
\text { - Konten pembelajaran dalam pembelajaran berbasis proyek mudah } \\
\text { dimengerti. } \\
\text { - Proses pembelajaran berbasis proyek sangat menarik. } \\
\text { - Pembelajaran berbasis proyek menciptakan forum diskusi dan } \\
\text { pertanyaan langsung yang dapat meningkatkan interaksi guru dan } \\
\text { peserta didik. } \\
\text { - Struktur pembelajaran berbasis proyek mudah diikuti. }\end{array}$ \\
\hline $\begin{array}{l}\text { Respon terhadap } \\
\text { kelebihan dan kekurangan } \\
\text { pembelajaran berbasis } \\
\text { proyek }\end{array}$ & $\begin{array}{l}\text { Sebagian besar ( } 51 \% \text { - } 75 \%) \text { peserta didik menyatakan bahwa: } \\
\text { - Pembelajaran berbasis proyek dapat meningkatkan motivasi belajar. } \\
\text { - Belajar melalui lingkungan memberikan cukup waktu untuk memahami } \\
\text { meteri pelajaran. } \\
\text { - Belajar melalui lingkungan melatih kemandirian peserta didik dalam } \\
\text { belajar. } \\
\text { - Belajar melalui lingkungan mudah dimengerti karena berdasarkan } \\
\text { pengalaman langsung. } \\
\text { - Belajar melalui lingkungan menghabiskan banyak biaya. } \\
\text { - Belajar melalui lingkungan terdapat banyak kesulitan. } \\
\text { - Belajar melalui lingkungan menghabiskan banyak waktu. }\end{array}$ \\
\hline
\end{tabular}




\begin{tabular}{ll}
\hline \multicolumn{1}{c}{ Aspek } & Hasil \\
\hline Respon terhadap berpikir & sebagian besar (51\% - 75\%) peserta didik menyatakan bahwa: \\
kreatif & Pembelajaran berbasis proyek melatih peserta didik dalam mengajukan \\
& pertanyaan tentang permasalahan lingkungan. \\
& Pembelajaran berbasis proyek melatih untuk memikirkan macam- \\
& macam cara yang berbeda untuk menyelesaikan masalah. \\
& Pembelajaran berbasis proyek melatih peserta didik untuk \\
& menggolongkan hal-hal menurut pembagian (kategori) yang berbeda. \\
- Pembelajaran berbasis proyek melatih peserta didik untuk memikirkan \\
hal-hal yang tidak terpikirkan oleh orang lain. \\
- Pembelajaran berbasis proyek melatih peserta didik untuk \\
mengemukakan pendapatnya sendiri terhadap suatu masalah. \\
- Pembelajaran berbasis proyek melatih peserta didik untuk \\
mengidentifikasi masalah lingkungan. \\
- Pembelajaran berbasis proyek melatih peserta didik untuk merumuskan \\
masalah lingkungan. \\
- Pembelajaran berbasis proyek melatih peserta didik untuk menemukan \\
alternatif-alternatif solusi tentang lingkungan. \\
- Pembelajaran berbasis proyek melatih untuk memilih alternatif solusi \\
tentang lingkungan.
\end{tabular}

Berdasarkan tabel 6, dapat diketahui bahwa tanggapan peserta didik pada beberapa aspek cukup baik, kecuali pada beberapa hal, dimana pembelajaran berbasis proyek memiliki beberapa kekurangan, diantaranya: pembelajaran berbasis proyek menghabiskan banyak biaya, menghabiskan banyak waktu, dan terdapat banyak kesulitan.

Tanggapan peserta didik mengenai pembelajaran berbasis proyek terhadap keterampilan berpikir kreatif peserta didik tentang makanan dan kesehatan pada penelitian ini menunjukkan tanggapan yang cukup baik. Hal ini dapat dilihat dari tanggapan peserta didik yang hampir setengahnya $(44,44 \%)$ menyatakan setuju bahwa mereka tertarik belajar melalui lingkungan. Slameto (2003) mengatakan bahwa ketertarikan peserta didik terhadap suatu pembelajaran merupakan salah satu faktor dalam keberhasilan pembelajaran.

Berdasarkan angket, dapat diketahui juga bahwa kemampuan berpikir kreatif peserta didik menjadi terlatih dengan mengikuti pembelajaran berbasis proyek. Hasil ini dapat terlihat dari sebagian besar $(65,92 \%)$ peserta didik menyatakan setuju bahwa pembelajaran berbasis proyek melatih mereka dalam mengajukan pertanyaan, memikirkan macam-macam cara yang berbeda untuk menyelesaikan masalah, menggolongkan hal-hal menurut pembagian (kategori) yang berbeda, memikirkan hal-hal yang tidak terpikirkan oleh orang lain, dan menentukan pendapat sendiri terhadap suatu masalah.

\section{SIMPULAN}

Berdasarkan hasil penelitian dan analisis data, maka dapat disimpulkan terdapat peningkatan kemampuan berpikir kreatifyang mendapatkan pembelajaran berbasis proyek secara signifikan lebih tinggi dibandingkan dengan peserta dididk yang mendapatkan pembelajaran secara konvensional.

\section{DAFTAR RUJUKAN}

Anderson, L.W. dan Krathwohl, D.R.(2015). Kerangka Landasan Untuk Pembelajaran,Pengajaran dan Asesmen. Yogyakarta: Pustaka Pelajar.

Arikunto, S. (2010). Prosedur Penelitian Suatu Pendekatan Praktek. Jakarta: Rineka Cipta.

Arikunto, S. (2012). Dasar-Dasar Evaluasi Pendidikan. Jakarta: Bumi Aksara. 
Aziz, S. (2014). Peningkatan Keterampilan Proses Sains Dan Keterampilan Berpikir kritis Melalui Pembelajaran Berbasis Proyek. (Tesis).Sekolah Pascasarjana, Universitas Pendidikan Indonesia, Bandung.

Badan Standar Nasional Pendidikan. (2007). Standar Pendidikan Nasional Indonesia untuk Satuan Pendidikan Dasar dan Menengah. Jakarta: Ditjendikdasmen.

Departemen Pendidikan Dasar. (2003). Undang-Undang Republik Indonesia, Nomor 20 Tahun 2003 Tentang Sistem Pendidikan Nasional. Jakarta: Depdikdas.

Firman, H. dan Widodo, A. (2008). Panduan IPA SD. Pusat Perbukuan.

Kadesastrika, A. I (2013). Pengaruh Model Pembelajaran Berbasis Proyek Terhadap Pemahaman Konsep Kimia Dan Keterampilan Berpikir Kritis. E-Journal Program Pascasarjana UNESA Program Studi Pendidikan IPA. Vol3 tahun2013[Online]

Ismayani, A. (2016). "Penerapan Project based Learning Dalam Pembelajaran Matematika Untuk Meningkatkan Kemampuan Komunikasi Matematis Dan Aktivitas Belajar Siswa”. Makalah pada Konferensi Nasional Penelitian Matematika dan Pembelajarannya (KNPMP I) 713 Universitas Muhammadiyah 2016, Surakarta.

Long, H. (2014). “An Empirical Review of Research Methodologies and Methods in Creativity Studies (20032012)”. Creativity Research Journal 26(4), 427 - 438.

Munandar, U. (1999). Mengembangkan Bakat dan Kreativitas Anak Sekolah. Jakarta: Gramedia.

Munandar, U. (2012). Pengembangan kreativitas anak Berbakat. Jakarta: Gramedia

Riduwan. (2004). Metode dan Teknik Menyusun Tesis. Bandung: Alfabeta.

Riduwan dan Sunarto. (2009). Pengantar Statistika Untuk Pendidikan, Sosial, Ekonomi, Komunikasi dan Bisnis. Bandung: Alfabeta.

Sistem Pendidikan Nasional. (2003). UU RI No. 20 Th. 2003 tentang Sistem Pendidikan Nasional. Bandung: Fokusmedia.

Schumacher. (2002). Research In Education. Addison Wesley Longmann, Inc.

Sistem Pendidikan Nasional. (2003). UU RI No. 20 Th. 2003 tentang Sistem Pendidikan Nasional. Bandung: Fokusmedia.

Sugiyono. (2010). Metode Penelitian Kuantitatif, Kualitatif dan R\&D. Bandung: Penerbit Alfabeta. 